\title{
Inquiry Based Teaching in an Animation Multimedia Course
}

\author{
https://doi.org/10.3991/ijet.v14i17.11387 \\ Yue Zheng \\ University of Science and Technology Liaoning, Anshan, China \\ $13804911577 @ 163 . \mathrm{com}$
}

\begin{abstract}
In the process of cultivating high-level animation talents, highquality animation course can play a crucial role, and effectively improve design and innovation ability. However, current animation course design and teaching also have obvious defects. The inquiry teaching of subject activity can play a positive role in training students' innovation and creation ability and thus effectively make up for the shortcomings in animation course teaching. In this study, animation multimedia course was taken for example to explore the design and teaching application practice of maker education method based on "activity inquiry". The maker teaching mode based on "activity inquiry" comprises four modules: teaching process, teaching objective, teaching design, and analysis of students' performance. On this basis, it was applied in the teaching practice of animation multimedia course. Besides, the decision tree algorithm was innovatively adopted in this experiment to analyze students' performance, and decision-making tree analytical framework for students' performance was constructed, including data acquisition, data preprocessing, data classification \& mining, and classification rule generation. Finally, the teaching test results indicate that the proposed teaching mode can significantly improve teaching effect, and actively promote students' core ability training in terms of animation design and creation.
\end{abstract}

Keywords-Activity inquiry; analysis of students' performance; animation course; maker

\section{Introduction}

The animation industry refers to the industry in which the originality is the core element, and animation and peripheral products are designed, developed, performed and sold. Because of its broad and profound development prospect, this industry is also praised as an emerging sunrise industry and listed as the key development industry by many countries [1]. The animation industry is a typical technology-intensive industry, and has very high requirements for innovation and creation ability [2]. Cultivating high-level animation talents plays a decisive role for enhancement of animation industry competitiveness and long-term development. In the process of cultivating highlevel animation talents, high-quality animation course can play a crucial role, and 
effectively improve design and innovation ability. However, in current talent training system of China, animation course design and teaching also have obvious defects. On the one hand, present animation course is still dominated by drawing skill explanation and learning, and the cultivation for students' innovation and creation ability is still deficient. On the other hand, students' active participation and subjective initiative fail to be fully exerted in animation course teaching process, thus leading to the difficulty in fully training students' practical operation ability.

Currently, with the rapid development of animation industry, high-level animation talents are also badly needed. For the shortcomings of animation course teaching, driving animation course reform to improve students' innovation and creation ability has become an inevitable choice. The inquiry teaching of subject activity can not just give full play to students' subjective initiative and enhance students' participation in teaching, but also play a positive role in cultivating students' innovation and creation ability and effectively make up for the defects in animation course teaching. Thus, the animation multimedia course was taken for example to probe into the design and teaching application practice of maker teaching method based on "activity inquiry".

\section{State of the Art}

Maker concept refers to keeping exploration of one's ideas through continuous practice, cooperation, innovation and sharing and transforming them to reality [3]. Introducing maker idea in education forms the teaching practice mode of maker teaching method. Compared with traditional exam-oriented teaching mode, a lot of situations are designed and created in the maker teaching method to guide students for continuous innovation and practice [4]. The maker teaching method can significantly drive cultivation of students' innovative and practical ability. Hence, it is widely practiced in the teaching design of many courses. For example, Li [5] applied maker teaching design method based on "inquiry of main activities" in the course design of App Inventor, and effectively achieved the teaching objective of cultivating students' ability of creative thinking. Huang [6] explored the application of make teaching method in modern vocational education through theoretical analysis and practical application and believed that maker teaching method conforms to the development direction of modern vocational education and plays a very significant role for students' ability cultivation and future development. Meanwhile, educators are also continuously exploring and updating the improvement of creative teaching mode for animation major. Klenk et al. [7] confirmed whether a teaching method like computer animations is more effective than a traditional textbook-only method in helping students in Grade 9 learn an abstract concept of planetary retrograde motion.

The purpose of teaching method innovation is to improve the teaching effect, so a scientific and effective teaching effect evaluation method is essential. Traditional teaching effect evaluation method is mainly examination, and the students' score is used to represent the teaching effect. However, the score of one examination cannot truly and accurately reflect the teaching effect, and even the examination score has large deviations with the real conditions. To evaluate the teaching effect more truly in 
the teaching reform, many new methods to analyze students' performance have appeared. For instance, Husain et al. [8], based on human capital, applied the mean and the Spearman Rho correlation method to analyze students' performance, and gained the good teaching evaluation effect. Yang et al. [9], based on decision tree algorithm, proposed a student course analysis method, overall considered students' ordinary performance and scores of multiple examinations, and obtained the high authenticity and accuracy. Based on data mining method, put forward a regression model to analyze students' performance, and this model can evaluate teaching effect more scientifically.

To resolve the defects in current animation major teaching, the maker teaching method was applied in teaching design and practice of animation multimedia course. The innovations of this study are reflected in three aspects. Firstly, "activity inquiry" and maker teaching method were organically combined, and they were applied in animation multimedia course teaching. In this way, students' subjective initiative and leading role in teaching could be fully exerted. This method can play a positive role in promoting students' practical and innovative ability. Secondly, in combination of actual situations of animation multimedia course teaching, a new teaching evaluation method was proposed based on decision-making tree theory in this study to analyze students' scores in the course. This method can play an effective role for scientific evaluation of teaching effect and targeted improvement. At last, the maker teaching method was fully utilized in teaching design and practice of animation multimedia course. Such teaching framework very fits with innovative and practical ability training requirements for animation talents, in the hope of providing the thought and method for animation major training mode.

\section{Maker Teaching Mode Based on "Activity Inquiry"}

\subsection{General process of "activity inquiry" teaching}

"Activity inquiry" teaching [10] means in the teaching process, teachers let students observe, read, think, practice and discuss independently or in groups through problem and situation design so as to actively discover and master knowledge. "Activity inquiry" teaching attaches importance to students' leading position and subjective initiative, and cultivate students' ability to analyze and solve problems. In accordance with the definition and feature of "activity inquiry" teaching, the whole process can be divided into the four stages [11]:

- Preparation stage: The main participant in this stage is the teacher, and the task to be completed is to design the appropriate exploration activity for teaching implementation based on deep analysis of teaching content.

- Teaching implementation stage: The teacher and students will together participate in this stage, but the teacher serves as the observer and guide, while students are the subjects of activity inquiry. The teacher is responsible for importing the situation for students, discovering students' problems in the exploration process and 
guiding them. Students collect information, think over the solutions and implement them on the basis of sufficient observation.

- Sharing and exchange stage: In this stage, students are still the subjects, display the learning achievements of inquiry learning to the teacher and students, interact and discuss deeply. The teacher also joins in the discussion and properly guides students in this stage.

- Evaluation and self-examination stage: Based on students' self-assessment and group evaluation, the teacher will carry out summative evaluation of the whole inquiry learning process to enhance students' knowledge understanding and skill mastery. Fig. 1 displays the general process of "activity inquiry" teaching.

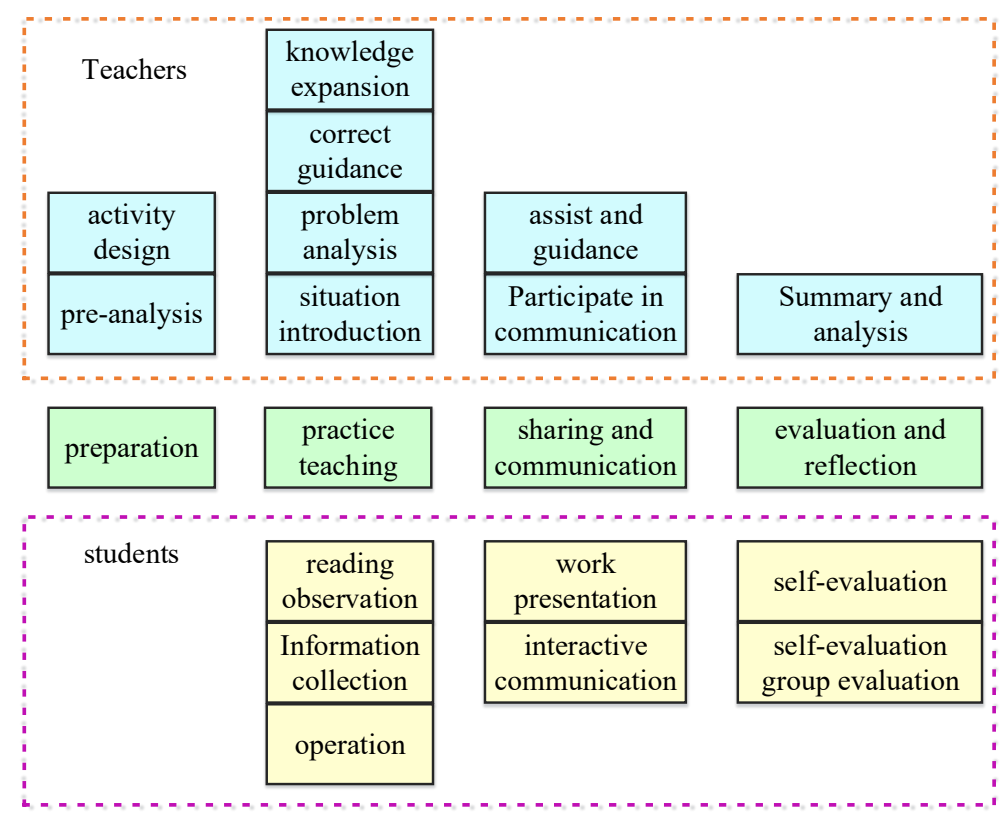

Fig. 1. General process of "activity inquiry" teaching

\subsection{Teaching process of maker teaching method based on "activity inquiry"}

The maker teaching method based on "activity inquiry" organically combines activity inquiry and maker teaching. In other words, the teacher designs innovative situation and let students actively solve problems through innovation. Such teaching method can not just give play to the advantages of "activity inquiry" teaching method in cultivating students' practical ability, but also promote students' innovation ability. In such teaching method, the key is to integrate maker thinking in teaching activity design and let students give play to their innovation ability to complete the tasks in teaching activities. 


\subsection{Training objective of maker teaching method based on "activity inquiry"}

According to the teaching process of maker teaching method based on "activity inquiry", the basic training objectives are determined, as shown in Table 1.

Table 1. Training objective of maker teaching method based on "activity inquiry"

\begin{tabular}{|c|c|}
\hline Training objective & Major performance \\
\hline Learning interest & $\begin{array}{l}\text { Full of keen interest in learning, able to take active part in various kinds of } \\
\text { learning activities, and actively exchange with students and teachers about the } \\
\text { learning achievements }\end{array}$ \\
\hline $\begin{array}{l}\text { Cognition and understand- } \\
\text { ing of knowledge }\end{array}$ & $\begin{array}{l}\text { Able to proficiently understand and master course knowledge and skills, and } \\
\text { effectively apply them to solve relevant problems }\end{array}$ \\
\hline Innovative thinking & $\begin{array}{l}\text { Able to effectively propose innovative schemes through thinking divergence } \\
\text { in the problem solving process or when difficulties are met }\end{array}$ \\
\hline $\begin{array}{l}\text { Communication and expres- } \\
\text { sion }\end{array}$ & $\begin{array}{l}\text { Able to actively and effectively communicate with other members and the } \\
\text { teacher in the inquiry process, and accurately convey the ideas to other mem- } \\
\text { bers and the teacher }\end{array}$ \\
\hline Teamwork & Able to solve complex problems through teamwork \\
\hline $\begin{array}{l}\text { Problem analysis and solv- } \\
\text { ing }\end{array}$ & $\begin{array}{l}\text { Able to deeply analyze problems and overall apply the knowledge and skills to } \\
\text { effective solve problems }\end{array}$ \\
\hline
\end{tabular}

\section{4 "Subject activity inquiry" teaching design mode based on characteristics of animation major}

"Subject activity inquiry" teaching design mode based on characteristics of animation major takes learning activity organization and implementation as the center. The teacher is responsible for organizing, designing and guiding the teaching activity, while students are the subjects of learning activity implementation. "Subject activity inquiry" teaching design mode based on characteristics of animation major is shown in Fig.2.

- The teacher deeply and overall analyzes teaching content and teaching object, and determines the teaching objective and knowledge points on this basis.

- According to the teaching objectives and knowledge points, the teacher designs corresponding learning activity sequence and constructs the supporting environment required by learning activity implementation.

- The teacher organizes the learning activity sequence and implements the teaching activity to let students grasp knowledge and skills in the activity.

- The teacher organizes course summarization and evaluation, sums up knowledge, reflects defects and improves them. Fig.2 shows "subject activity inquiry" teaching design mode based on characteristics of animation major. 


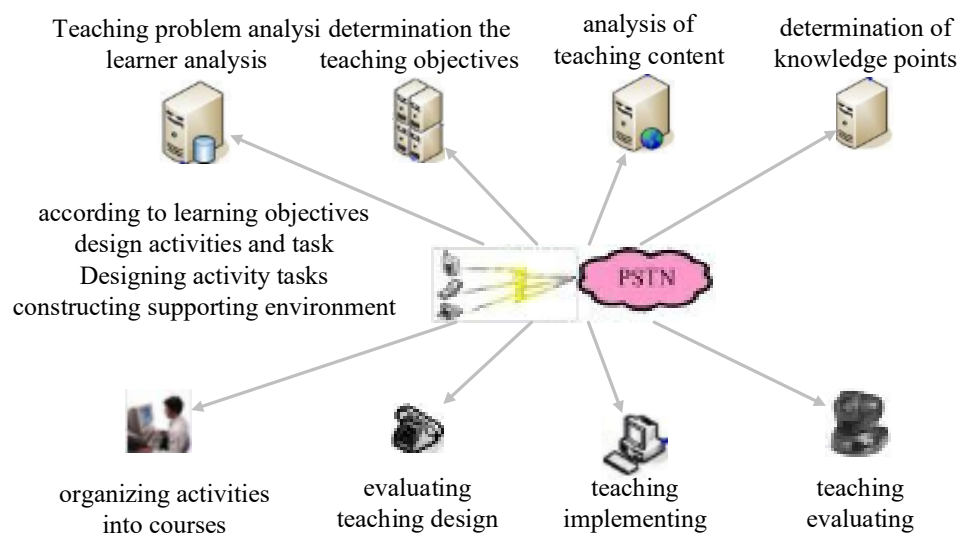

Fig. 2. "Subject activity inquiry" teaching design mode based on characteristics of animation major

\subsection{Analysis of students' performance of "subject activity inquiry" teaching mode}

One of the main purposes for analysis of students' performance is to classify so as to mine valuable information for course evaluation and improvement. The decisionmaking tree is an example-based sorting technique, and can construct a decisionmaking tree according to a group of chaotic examples so as to classify and predict data. The decision tree algorithm has the advantages of fast speed, high accuracy and easy understanding, and owns strong scalability so that it can be used for both continuous data and discrete data. In "subject activity inquiry" teaching mode, single exam score cannot accurately reflect students' learning effect, and comprehensive and allround evaluation should be conducted. Thus, based on decision tree algorithm, student performance analysis framework was proposed in this study, including four steps: data acquisition, data preprocessing, data classification \& mining, and classification rule generation. Fig. 3 displays the iterative process of decision-making tree model building.

Data acquisition: To overall reflect students' learning effect, students' performance data will include ordinary classroom performance and test score. Classroom performance contains class attendance, activity participation, and communication. Test score covers phased test score, activity score and final exam score.

Data preprocessing: Before the decision tree algorithm is used to analyze students' performance, first of all, all score data should be discretized, that is, quantitative continuous data are converted into discrete data as per the preset rules. In discretization treatment, the scores are classified into 5 categories from low score to high score according to students' aggregate performance, and corresponding continuous data interval is set.

Data classification and mining: Data classification and mining method was applied in this study to establish the decision-making tree for students' performance. Multiple iterations of the algorithm are required to establish the optimal model. The 
iteration process of decision-making tree model building algorithm is shown in Fig.33. In the iteration process of the algorithm, information entropy is used to measure the advantage and disadvantage of current decision. The calculation of information entropy is based on information. The information amount calculation formula of sample classification result is shown in Formula (1).

$$
\inf o(D)=-\sum_{i=1}^{m} p_{i} \log _{2}^{p_{i}}
$$

The information entropy of sample classification can be calculated by Formula (2).

$$
\inf o_{A}(D)=\sum_{j=1}^{v} \frac{\left|D_{j}\right|}{|D|} \times \inf o\left(D_{j}\right)
$$

During comparing the evolution degree of two iterations, information gain rate is used to measure. The calculation method is shown in Formula (3).

$$
\operatorname{Gainratio}(A)=\frac{\operatorname{Gain}(A)}{\operatorname{SplitInfo}_{A}(D)}
$$

Wherein,

$$
\operatorname{Gain}(A)=\inf o(D)-\inf o_{A}(D)
$$

$$
\text { Splitinf } o_{A}(D)=-\sum_{j=1}^{v} \frac{\left|D_{j}\right|}{|D|} \times \log _{2}\left(\frac{\left|D_{j}\right|}{|D|}\right)
$$

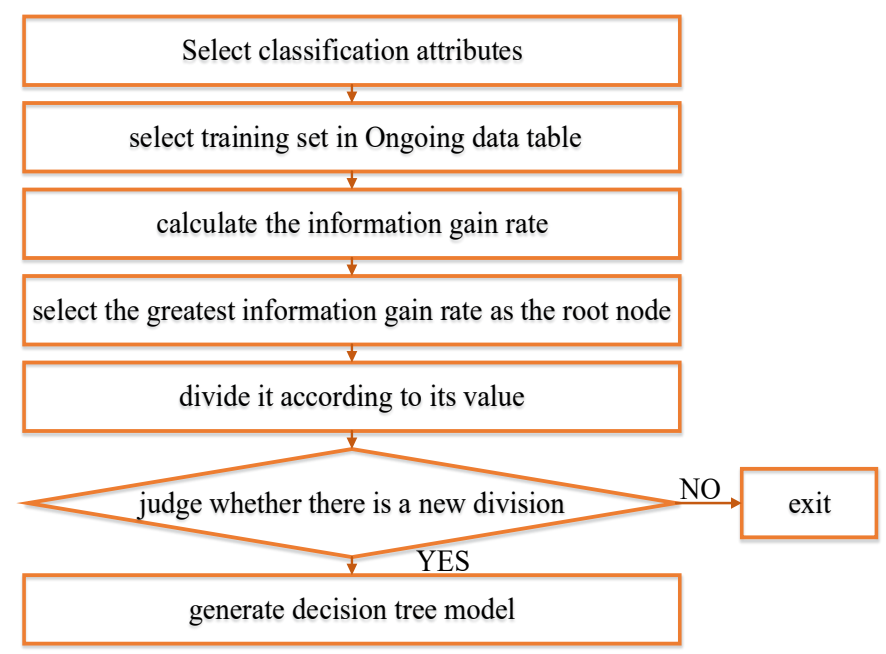

Fig. 3. Iteration process of decision-making tree model building algorithm 
Classification rule generation: After the optimal decision-making tree model is generated by the iteration, each route from the root node to leaf node forms a classification rule which can be used to classify and analyze students' performance.

\section{$4 \quad$ Teaching Example and Effect}

\subsection{Teaching example}

In animation multimedia course, the maker teaching method bawd on "subject activity inquiry" was applied in the module of "production of animation promotional film". The teaching design and implementation process includes four parts, as shown in Table 2 Teaching design and implementation process of animation promotional film production. Figs.4-5 show the application of maker teaching method based on "activity inquiry" in animation software. Fig.6 is the display link of animation multimedia classroom based on "activity inquiry".

Table 2. Teaching design and implementation process of animation promotional film production

\begin{tabular}{|c|c|c|}
\hline \multicolumn{3}{|c|}{ I. Early preparation } \\
\hline \multicolumn{3}{|c|}{$\begin{array}{l}\text { Teaching objectives } \\
\text { 1) Master basic knowledge and skills to produce animation promotional film } \\
\text { 2) Be able to rationally apply tools to solve problems in the film production process } \\
\text { 3) The film produced has certain innovation and artistry. } \\
\text { Activity design } \\
\text { In the course, students will apply the knowledge and skills to produce a short film for animation promotion } \\
\text { by focusing on a specific theme. In the teaching activity design, the teacher determines the theme of pro- } \\
\text { motional film and the specific production requirements. }\end{array}$} \\
\hline \multicolumn{3}{|c|}{ II. Teaching implementation } \\
\hline Teacher activity & Student activity & Teaching intention \\
\hline $\begin{array}{l}\text { Situation importing: } \\
\text { Explain the theme and produc- } \\
\text { tion requirements of promotional } \\
\text { film to students }\end{array}$ & $\begin{array}{l}\text { Analyze the theme and production require- } \\
\text { ments of promotional film, and build the } \\
\text { production team }\end{array}$ & $\begin{array}{l}\text { Let students understand the } \\
\text { basic requirements of the } \\
\text { activity }\end{array}$ \\
\hline $\begin{array}{l}\text { Observe the process in which } \\
\text { students produce the film }\end{array}$ & $\begin{array}{l}\text { 1) Determine the production thought and } \\
\text { confirm the work division } \\
\text { 2) Apply the knowledge and skills learned } \\
\text { to product the film } \\
\text { 3) Carry out communication and exchange } \\
\text { at the regular time to make sure the film is } \\
\text { produced smoothly }\end{array}$ & $\begin{array}{l}\text { Let students master the } \\
\text { knowledge and skills of film } \\
\text { production in the activity }\end{array}$ \\
\hline \multicolumn{3}{|c|}{ III. Sharing and exchange } \\
\hline \multicolumn{3}{|c|}{$\begin{array}{l}\text { 1) Let each team display the production result in the class, and introduce the thought, design and innova- } \\
\text { tion. } \\
\text { 2) Organize students to exchange and discuss the problems in the production process }\end{array}$} \\
\hline \multicolumn{3}{|c|}{ IV. Evaluation and self-examination } \\
\hline \multicolumn{3}{|c|}{$\begin{array}{l}\text { Teaching process summarization } \\
\text { The teacher sums up and concludes the general problems in the teaching process, and guides students to } \\
\text { propose improvement scheme so as to avoid them in the future. } \\
\text { Course evaluation } \\
\text { Distribute questionnaires to students and let students complete evaluation feedback. }\end{array}$} \\
\hline
\end{tabular}




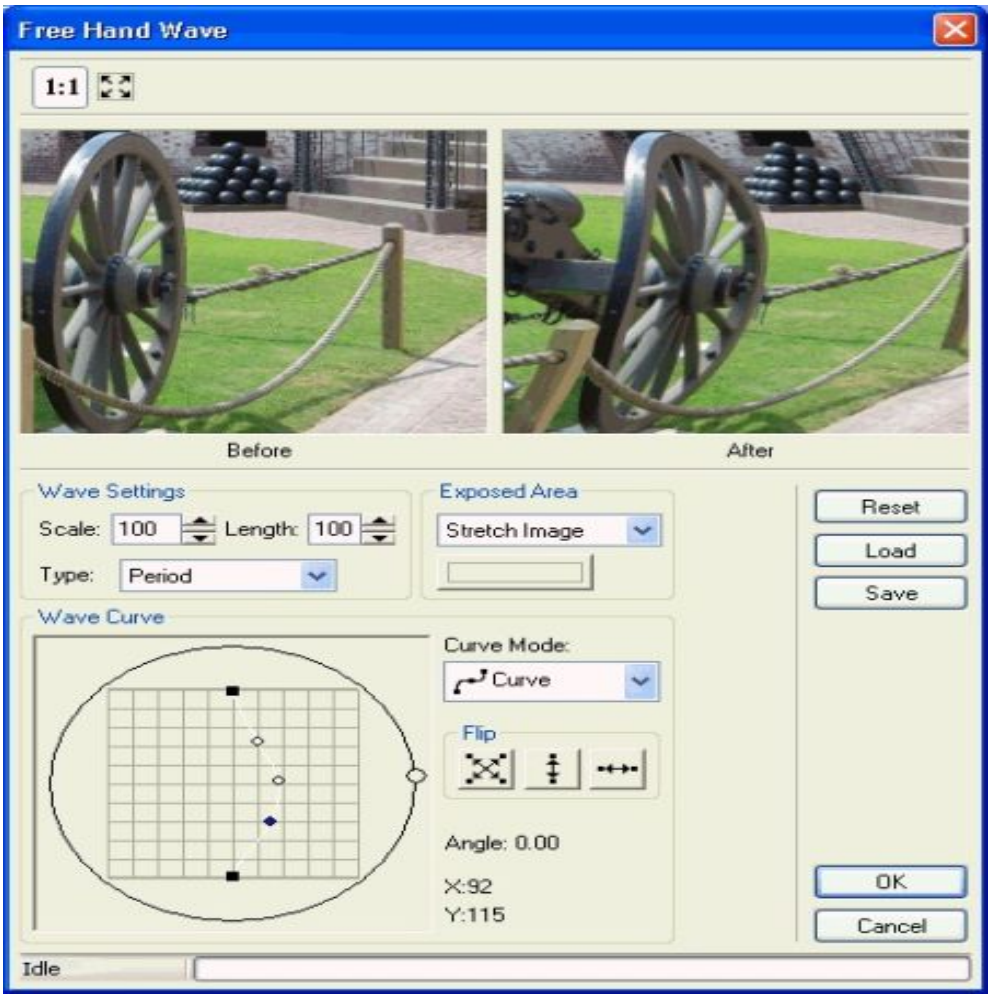

Fig. 4. Application display I of maker teaching method based on "activity inquiry" in animation software

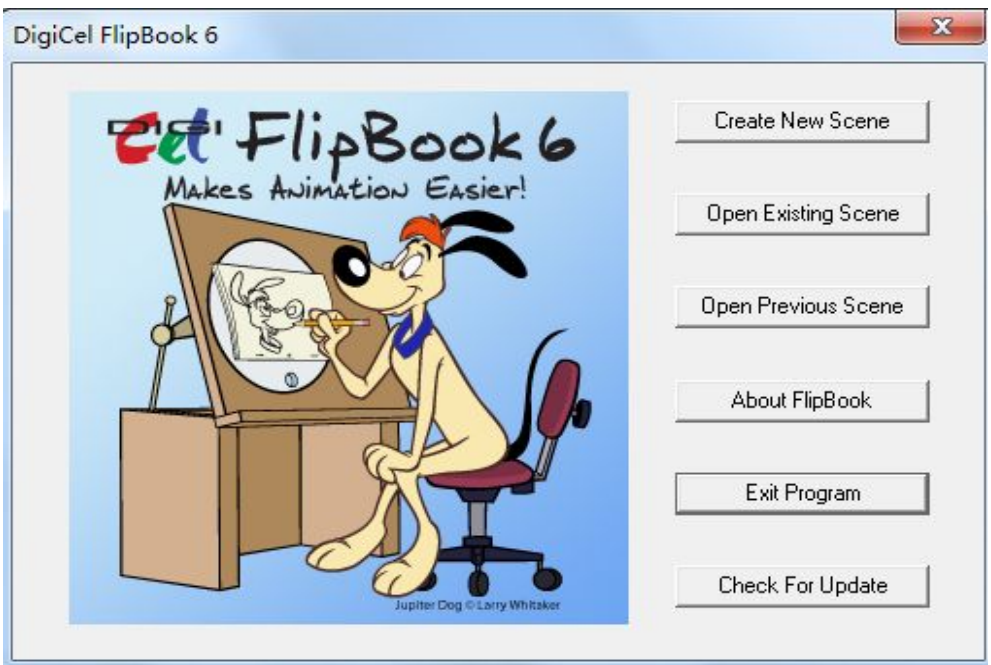

Fig. 5. Application display II of maker teaching method based on "activity inquiry" in animation software 


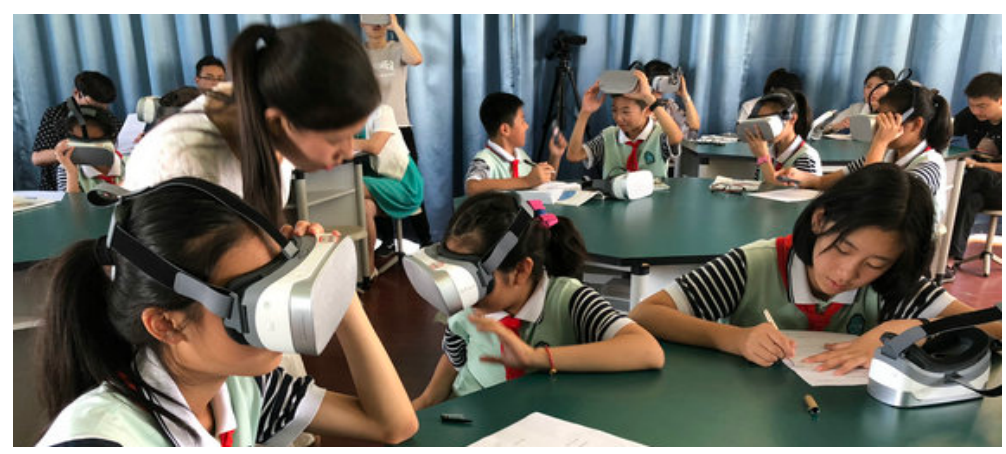

Fig. 6. Classroom Display Link Based on "Activity Inquiry"

Note: Pictures from http://edu.anhuinews.com/system/2018/06/08/007890635.shtml

\subsection{Teaching effect}

The questionnaire method was applied in this study to investigate the application effect of maker teaching method based on "activity inquiry" in animation multimedia course. The questionnaire aims to evaluate students' mastery of core abilities required in animation design and creation, including 6 times: learning interest, cognition and understanding of animation creation and design, innovative thinking, communication and expression, teamwork, and problem analysis and solving. Students gave corresponding feedback in each item within the scope of 1-10 scores according to visual analogue scale. 1 is the lowest score, while 10 represents the highest score. In selection of objects, one experimental class and one control class were confirmed. The maker teaching method was used for the experimental class in animation multimedia course, while traditional teaching method was adopted for the control class. There were 46 students in the experimental class, and 46 effective questionnaires were collected, with the recovery rate of $100 \%$. There were 47 students in the control class, and 46 effective questionnaires were collected, with the recovery rate of $97 \%$. T test was conducted for the scores of 8 items fed back by students to confirm whether the learning effect of experimental class is significantly higher than that of control class. According to Formula 4-1, $t$ value can be gained, and thus $p$ value can be gained. If $o$ value is less than 0.05 , the difference between the two is significant. The learning effect test results of both classes are shown in Table 3 .

Table 3. Teaching effect evaluation table of two classes

\begin{tabular}{|l|c|c|c|c|}
\hline \multicolumn{1}{|c|}{ Item } & Experimental class & Control class & t & p \\
\hline Learning interest & $8.80 \pm 0.98$ & $7.54 \pm 1.02$ & 4.72 & $<0.001$ \\
\hline $\begin{array}{l}\text { Cognition and understanding of animation } \\
\text { creation and design }\end{array}$ & $8.79 \pm 1.05$ & $7.01 \pm 1.12$ & 5.01 & $<0.001$ \\
\hline Innovative thinking & $8.89 \pm 0.87$ & $7.21 \pm 1.09$ & 4.89 & $<0.001$ \\
\hline Communication and expression & $8.73 \pm 0.86$ & $7.33 \pm 1.21$ & 4.77 & $<0.001$ \\
\hline Teamwork & $9.01 \pm 0.93$ & $7.22 \pm 1.26$ & 4.92 & $<0.001$ \\
\hline Problem analysis and solving & $9.34 \pm 1.01$ & $7.01 \pm 1.19$ & 4.88 & $<0.001$ \\
\hline
\end{tabular}


Seeing from the average score of the 6 items, the average score of experimental class is higher than that of control class. Based on this, hypothesis testing method was used to analyze the significance of this difference. $P$ values of test results of 8 items are less than 0.05 , indicating that the average score of experimental class is higher than that of control class. This means the maker teaching method based on "activity inquiry" can significantly improve teaching effect of animation multimedia course, and can actively promote cultivation of students' core abilities in animation design and creation.

\section{Conclusion}

In this study, animation multimedia course was taken for example to explore the design and teaching application practice of maker education method based on "activity inquiry". The maker teaching mode based on "activity inquiry" comprises four modules: teaching process, teaching objective, teaching design, and analysis of students' performance. On this basis, the teaching mode was applied in the teaching practice of animation multimedia course. In the animation multimedia course, the maker teaching mode based on "subject activity inquiry" was applied in the module of "production of animation promotional film". In teaching effect testing, the teaching effect of the proposed method was tested by comparing the teaching effect of experimental class and control class. The teaching test results show that the proposed teaching mode can significantly improve the teaching effect and actively promote cultivation of students' core abilities required in animation design and creation. The defect of this study is that during communication with students, our mandarin was not standard enough so that students' attention was often decentralized. Thus, the teacher must own basic skills and should not let some potential problems affect students' learning state. Secondly, it is found after teaching result evaluation that, the method lacks cultivation of students' logical thinking ability. Therefore, we also need to keep exploring in this field.

\section{Acknowledgement}

This work was supported by a Research Fund Project for Young Teachers of Liaoning University of Science and Technology (2018QN17).

\section{$7 \quad$ References}

[1] Yoon, H., Malecki, E.J. Cartoon planet: worlds of production and global production networks in the animation industry. Industrial and Corporate Change, 2009, vol. 19(1), pp. 239-271. https://doi.org/10.1093/icc/dtp040

[2] Van Egeraat, C., O'Riain, S., \& Kerr, A. Social and spatial structures of innovation in the Irish animation industry. European planning studies, 2013, vol. 21(9), pp. 1437-1455. https://doi.org/10.1080/09654313.2012.755838 
[3] Yang, X.M., Li, Y.H. The Potential Value of Maker Education and Its Disputes. Modern Distance Education Research, 2015, vol. 27(2), pp. 23-34.

[4] Zhu, Z.T., Liang, L. From Creator Movement to Creator Education: Cultivating Creator Culture. e-Education Research, 2015, vol. 36(7), pp. 5-13.

[5] Li, Z.X., Zhang, X.Q. Construction of School Experience-oriented Hackerspace for Primary and Secondary School Students. Teaching of Forestry Region, 2018, vol. 34(3), pp. 115117.

[6] Huang, B.S., Wang, L. An Analysis on the Application of Modern Apprenticeship in Vocational Education Based on the Perspective of Maker Education. The Science Education Article Cultures, 2018, vol. 422(5), pp. 121-122.

[7] Elmstrom Klenk, K. Computer animation in teaching science: effectiveness in teaching retrograde motion to 9th graders. A Doctoral Dissertation of Philosophy in Education University of Rhode Island and Rhode Island College. 2011.

[8] Husain, H., Misran, N., Arshad, N., et al. Analysis on Electrical and Electronics Engineering Students' Academic Achievement. Procedia-Social and Behavioral Sciences, 2012, vol. 60, pp. 112-118. https://doi.org/10.1016/j.sbspro.2012.09.355

[9] Yang, X.M., Hu, M.M., Tan, Y. Dynamical Incremental Learning Algorithm of Traffic Model for Software-Defined Networks. Journal of South-Central University for Nationalities (Natural Science Edition), 2018, vol. 37(2), pp. 102-107.

[10] Khalid, T. An integrated inquiry activity in an elementary teaching methods classroom. Science Activities, 2010, vol. 47(1), pp. 29-34. https://doi.org/10.1080/0036812090327401 $\underline{9}$

[11] Royer, A.M., Schultheis, E.H. Evolving Better Cars: Teaching Evolution by Natural Selection with a Digital Inquiry Activity. American Biology Teacher, 2014, vol. 76, pp. 259264. https://doi.org/10.1525/abt.2014.76.4.8

\section{Author}

Yue Zheng is a lecturer in the University of Science and Technology Liaoning, Anshan, China (13804911577@163.com).

Article submitted 2019-06-17. Resubmitted 2019-07-19. Final acceptance 2019-07-25. Final version published as submitted by the authors. 